\title{
Geopolitics, Ethnopolitics and the EU: The Cases of Serbia and Latvia
}

\section{Vassilis Petsinis}

To cite this article: Vassilis Petsinis (2019): Geopolitics, Ethnopolitics and the EU: The Cases of Serbia and Latvia, Ethnopolitics

To link to this article: https://doi.org/10.1080/17449057.2019.1630943

曲 Published online: 18 Jun 2019.

Submit your article to this journal 지

View Crossmark data $\nearrow$ 


\title{
Geopolitics, Ethnopolitics and the EU: The Cases of Serbia and Latvia
}

\author{
VASSILIS PETSINIS \\ Johan Skytte Institute of Political Studies, University of Tartu, Estonia
}

\begin{abstract}
This work is a study on the patterns of managing ethnic relations in Serbia and Latvia. It aims at enhancing the cross-regional exchange of knowledge between the Western Balkans and the Baltic States. This study demonstrates that as the bond between geopolitics and ethnopolitics grows more powerful, the liberalization of minority policies would become less feasible within a state. It also hints that the intersection between geopolitics and ethnopolitics should not be perceived as 'fixed' but it can be subject to fluctuations and readjustments.
\end{abstract}

\section{Introduction}

This article is a comparative study on the patterns of managing ethnic relations in Latvia and Serbia. The prospects of joining the EU have long formed a pole of attraction for Central and Eastern European states. One of the terms for accepting post-Communist states into the EU, set out in the Copenhagen Criteria (1993), is an adequate protection of the rights and freedoms of national minorities. ${ }^{1}$ Nevertheless, the management of ethnic relations has been interceded, to varying degrees, with geopolitical concerns throughout Central and Eastern Europe. Assessing whether and how regional geopolitics might interweave with domestic ethnopolitics and the management of ethnic relations can bring about innovative insights in this respect.

A variety of factors interact in the management of ethnic relations in the two country cases: Latvia $^{2}$ and $\mathrm{Serbia}^{3}$; the largest minority groups resident in each state (Serbia: ethnic Hungarians, Latvia: ethnic Russians ${ }^{4}$ ); their external homelands (Russia and Hungary); and the EU. Latvia is a full-fledged member state of the EU since 2004, whereas Serbia remains stranded along the path of a non-linear and complicated accession process. Nevertheless, the management of ethnic relations has been mediated, to varying degrees, by geopolitical concerns in both countries, and this provides a crucial common denominator between the two.

The choice of these two country cases and this comparison are not random because the varying intersection (or convergence) between ethnopolitics and geopolitics has been endemic in various ethnically diverse societies across Central and Eastern Europe (e.g. Estonia, Slovakia, Romania, and Croatia) (Aalto, 2003; Craiutu, 1995; Vasilijević, 2002). More importantly, this comparative study contributes additional empirical material 
to support the argument that as the bond between regional geopolitics and domestic ethnopolitics grows stronger, the liberalization of minority policies within a given state becomes less and less feasible. This article builds on the foundations of previous comparisons between Western Balkan (Croatia) and Baltic (Estonia) ethnopolitics (Petsinis, 2016), thus further contributing to the cross-regional exchange of knowledge between these two peripheries of Europe.

The main argument of this study is that one can observe the persistent convergence between regional geopolitics (bilateral relations with Russia) and domestic ethnopolitics (the collective status of the ethnic Russian minority) in Latvia. Meanwhile, in Serbia, the ruling elites put a greater weight on geopolitical considerations, namely the desire to preserve Serbia's 'neutrality' between East and West (occasionally comprising pro-Kremlin oscillations). Consequently, the centrality of domestic ethnopolitics has weakened within the Serbian context.

The main question here is: How and why do domestic ethnopolitics intercede with regional geopolitics in the two states compared? This article demonstrates that in Serbia systemic transformation brought about the relaxation of the intersection between geopolitics and ethnopolitics, and this facilitated the EU's external engagement on minority rights. By contrast, in Latvia, the convergence between geopolitics and ethnopolitics remains intact, and therefore the opportunity structure towards further liberalizing the legal framework on minority rights has been more restricted in comparison to Serbia.

The focus is on the management of ethnic relations in Latvia and Serbia and its evolution from the 2000s until present day with occasional references to the 1990s where deemed necessary. This article is situated inside the framework of a political analysis. Nevertheless, background references to the developments in the field of minority legislation in Latvia and Serbia are made when judged appropriate. This article has been structured according to the pattern of a thematic and paired comparison (Tarrow, 2010). A paired comparison can correct generalizations from single case studies and test the validity (or universality) of older conclusions that the researcher has reached. It can also operate as an intermediate step between a single case-study, which suggests a general relationship, and a multi-case analysis that tests or refines a theory. Within the frame of this study, the Latvian part of the comparison can help assess the validity (or universality) of the observations that I have made during my previous research on Serbia and the former Yugoslavia.

This work has also relied on: (a) legal documents concerning minority rights and public surveys; (b) semi-structured interviews with political representatives and activists, NGOs, and locally-based academic researchers (political scientists and sociologists) with an expertise in nationalism, ethnopolitics, and geopolitics. The research embeds this information in scholarly and theoretical literature in the thematic areas of ethnopolitics and nationalism. On the outset, this article sets the EU's soft power engagement on minority rights interacted with the endogenous factors of systemic transformation (Serbia) and the ethnic democracy model (Latvia) in a comparative context. Then, it examines the intersection among geopolitics, ethnopolitics, and the EU, as viewed by the political actors in each country, including a secondary reference to a grass-roots dimension. This study relies on Rogers Brubaker's triadic nexus theory, including the subsequent modifications of this nexus into a quadratic one.

\section{Between a Triadic and Quadratic Configuration of Ethnopolitics}

Rogers Brubaker originally proposed the triadic nexus theory (Brubaker, 1995, p. 112). According to the author, nationalism in multi-ethnic societies is often a dynamic interaction 
among the 'nationalizing state', the national minority (or minorities) living in that state, and the minority's (or the minorities') external national homeland (or kin state). A 'nationalizing state' is the one which subtly promotes the culture, language, and political primacy of the titular nation within the state through the governing institutions (ibid., p. 109). Each of these actors is not a static entity but a 'variably configured and continuously contested political field'. The interaction among these actors depends upon the relations and balances within each of them. Within this framework, the minorities' frequent response to the policies of the 'nationalizing state' is to push for more cultural or territorial autonomy and resist actual or perceived policies of discrimination. The role of the external homeland is to monitor the situation of their co-ethnics in the state in question, protest against alleged violations of their rights, and assert the right, even the obligation, to defend their interests.

The model of ethnic democracy can provide a trajectory for the nationalization of political institutions and the public space. Based on the Israeli precedent, Sammy Smooha defines an ethnic democracy as an arrangement that 'combines a structured ethnic dominance with democratic rights for all' (Smooha, 2001, p. 8). Ethnic democracy is 'democracy that contains the institutionalization of dominance of one ethnic group ... the "democratic principle" provides equality between all citizens and members of the society while the "ethnic principle" establishes preference and dominance' (ibid., pp. 24-25). Therefore, although providing the formal representative institutions of liberal democracy, ethnic democracy tends to restrict the participation of certain minority groups in the political processes.

Rogers Brubaker's matrix became topical inside the background of disputes over the collective statuses of ethnic minorities across Central and Eastern Europe during the 1990s. Considering the increasing significance of international organizations and supranational processes in Central and Eastern Europe, the prospect of EU-membership started functioning as a powerful pole of attraction for most post-Communist states. This enhanced the EU's soft power diplomacy vis-à-vis the candidate states. Soft power refers to the aggregate of the formal, as well as informal, mechanisms that the EU has employed in order to promote the compliance of the candidate states with the conditions that it has set for them (Bruszt \& Stark, 2003; Haughton, 2007). This development prompted several academic experts to reformulate Brubaker's triadic nexus into a quadratic one in light of the EU's eastward enlargement and to add the EU as a fourth actor inside the nexus (Budryte, 2005; Kelley, 2004; Pettai, 2006; Smith, 2002).

Due to its limited space, this work has relied upon David Smith's concept of quadratic nexus (Smith, 2002, 2003). In the author's own words, 'the role of international organizations should be central to any discussion of post-Communist identity politics in Central and Eastern Europe' (Smith, 2002, p. 9). Slightly amending the terminology used by Brubaker, Smith argues that 'Europeanization can thus be regarded as a variably configured and continuously contested political field in which different states, organizations, parties, movements or individual political entrepreneurs vie to impose their own particular political agenda' (ibid., p. 11). On numerous occasions, the author contends that it was the impact of the EU as a 'fourth pillar' that spurred the transition from 'nationalizing statehoods' to multiple 'integration strategies' since the year 2000 throughout Central and Eastern Europe (Smith, 2003).

At this point, it should be noted that a string of Central and East European states, throughout the 1990s, had endorsed the accession process to the EU from 'conditional' angles. Primary attention was paid to objectives such as foreign investment, freedom of movement, 
and the enhancement of regional security. Therefore, the external engagement of the EU and the Copenhagen Criteria over policy areas such as the management of ethnic relations inside the candidate states was frequently met with misunderstandings. A series of (usually right-wing) parties started formulating their nascent criticism of the EU along the lines that the EU 'imposes' minority rights from the exterior and weakens national sovereignty (Bustikova, 2015, 2018; Minkenberg, 2017; Pytlas, 2015). In the following sections, this theoretical framework is applied to a comparative overview of Serbia and Latvia and the analysis of the trajectories towards the management of ethnic relations in the two states since the 2000s.

\section{The Management of Ethnic Relations in Serbia and Latvia: Endogenous and Exogenous Factors}

\section{Systemic Transformation versus a Pattern of Continuity}

Ethnopolitics in Serbia and Latvia have been subject to the varying impact of both endogenous and exogenous catalysts. In Serbia, the most decisive transformation of the political landscape manifested through the transition from Slobodan Miloševićs rule, which was enacted after the parliamentary and presidential elections of 5 October 2000. A secondary and more recent transformation of the Serbian political map consists in the consolidation of President Aleksandar Vučić and the (nominally centre-right/conservative) Serbian Progressive Party/SNS (Srpska Napredna Stranka) as preponderant actors, especially following the presidential and parliamentary elections of 2016 and 2017. ${ }^{5}$ This development signalled an end to the high degree of fragmentation which persisted across Serbia's party-spectrum throughout most of the era following Slobodan Milošević's fall from power. To comprehend more adequately how systemic transformations interact with ethnopolitics in Serbia, some further elaboration and contextual analysis is required.

Throughout the 1990s, domestic ethnopolitics intertwined with regional geopolitics and the relations among the actors inside Brubaker's triadic nexus remained tense. The aggravation of the situation in Kosovo and the confrontation with the Euro-Atlantic institutions culminated in NATO's air campaign against the Federal Republic of Yugoslavia (MarchJune 1999). Meanwhile in Vojvodina, despite the general absence of violent conflict, there is evidence that the legislation on minority rights was not implemented promptly and that a 'renationalization' project had been initiated (Korhecz, 1998; Samardžić, 1998). Vojvodinian Hungarian parties (the Democratic Community of Hungarians in Vojvodina/VMDK and the Alliance of Hungarians in Vojvodina/VMSZ) refrained from cooperating with the Serbian democratic opposition and concentrated their efforts on internationalizing their grievances in the European forums (e.g. the COE and the OSCE) aided by a series of governments in Budapest (Arpasy, 1996, pp. 65-66) (Table 1).

The adoption of Resolution 1244 by the UN Security Council (1999) reaffirmed 'the sovereignty of the Federal Republic of Yugoslavia', but it de facto paved the way towards the enhancement of Kosovo's governing institutions and the recognition of its independence by powerful global actors. ${ }^{6}$ This development, in combination with the change of guard in Serbian politics, gradually resulted in the prioritization of geopolitical and foreign policy concerns by a sequence of governments in post-Milošević Serbia and the readjustment of the intersection between geopolitics and ethnopolitics. Serbian 
policymakers prioritized areas such as the redefinition of relations with Montenegro, cooperation with the ICTY, and relations with Republika Srpska in Bosnia while struggling to maintain Kosovo inside the administrative bounds of the Serbian republic (Noutcheva, 2007, pp. 17-18). Meanwhile, the management of ethnic relations within Serbia started forming a separate area of engagement in relation to regional geopolitics.

On the other hand, Latvia is characterized by a state of social stability although its partyspectrum has been subject to relatively elevated levels of fragmentation (Ikstens, 2013; Melenshevich, 2017). By contrast to Serbia, the political landscape of post-Soviet Latvia has displayed a greater continuity especially in regard to the endeavour to exclude parties suspected of pro-Kremlin leanings from the government structures (Nakai, 2014, pp. 74-76). One key feature of the Latvian party-system is the tendency of the ethnic Russian community to rally around parties with a civic (mostly the nominally centre-left Saskana/Harmony) instead of an explicitly ethnic profile as it is the case with the ethnic Hungarian minorities across the Carpathian basin.

Harmony's appeal to ethnic Russians, as well as its calls for a foreign policy of appeasement vis-à-vis Russia, has rendered their political rivals sceptical, to varying degrees, over the party's motives and reliability (Saarts, 2011). ${ }^{7}$ Despite its successful performance in a series of electoral contests, ${ }^{8}$ Harmony has been viewed as the outcast party by the (predominantly) Latvian parties and a cordon sanitaire has been formed around them. To keep

Table 1. The ethnic structure of the population in Vojvodina (2011 census)

\begin{tabular}{lcc}
\hline Nationality & Numbers & Percentages (\%) \\
\hline Serbs & $1,289,635$ & 66.76 \\
Hungarians & 251,136 & 13.00 \\
Slovaks & 50,321 & 2.60 \\
Croats & 47,033 & 2.43 \\
Roma & 42,391 & 2.19 \\
Romanians & 25,410 & 1.32 \\
Montenegrins & 22,141 & 1.15 \\
Bunjevci & 16,469 & 0.85 \\
Ruthenes & 13,928 & 0.72 \\
Yugoslavs & 12,176 & 0.63 \\
Macedonians & 10,392 & 0.54 \\
Ukrainians & 4,202 & 0.22 \\
Muslims & 3,360 & 0.17 \\
Germans & 3,272 & 0.17 \\
Albanians & 2,251 & 0.12 \\
Slovenes & 1,815 & 0.09 \\
Bulgarians & 1,489 & 0.08 \\
Gorani & 1,179 & 0.06 \\
Russians & 1,173 & 0.06 \\
Bosnjaks & 780 & 0.04 \\
Vlachs & 170 & 0.01 \\
Others & 6,170 & 0.35 \\
Regional affiliation & 28,567 & 1.48 \\
Non-defined & 81,018 & 4.19 \\
Unknown & 14,791 & 0.77 \\
TOTAL & $\mathbf{1 . 9 3 1 . 8 0 9}$ & $\mathbf{1 0 0}$ \\
\hline
\end{tabular}

Source: Republički Zavod za Statistiku, Popis 2011, (http://popis2011.stat.rs/). 
Harmony away from the halls of power, the previous coalition government comprised parties as diverse as Unity (centre-right, liberal/conservative), the Farmers and Greens Union (agrarian conservative) and the National Alliance (nationalist/right-wing populist).

This issue entails further elaboration and contextual discussion of state building. In Latvia (as in Estonia), the state institutions have been structured in accordance to the restorationist and ethnic democracy model (Aalto, 2003; Agarin, 2016; Mole, 2012) with an overriding emphasis on the primacy of the Latvian language in the state bureaucracy, education, and the public sector. The state institutions have been fashioned in such a way as to mirror the 'ethnic state of the Latvians/Estonians', finally restored after its suppression by the Soviets (Budryte, 2005). The bulk of post-war settlers, mostly ethnic Russians, were rendered 'stateless' and had to start a complex process of naturalization to acquire Latvian citizenship. This corresponded to restrictions in their political participation (Salonari, 2007, pp. 323-326; Van Elsuwege, 2004, pp. 21-23). It was not until the national referendum of 1998 that the Law on Citizenship (1995) was amended and allowed for the children of non-citizens born after independence to obtain citizenship by registration (Muižnieks, 2006a, pp. 15-17). ${ }^{9}$

Within the contexts of post-Soviet Latvia and Estonia, the ethnic democracy model has also been legitimized as part of the endeavour to guarantee the continuous survival of the titular nations inside an insecure geopolitical environment, in light of Russia's leverage as the external homeland for ethnic Russians (Ijabs, 2016, pp. 13-15). This pattern of continuity in domestic politics has preserved the convergence between geopolitics and ethnopolitics in Latvia.

\section{The Intersection between Geopolitics and Ethnopolitics: Readjustment versus Maintenance}

The relaxation of the intersection between ethnopolitics and geopolitics prompted the readjustment of the interaction between endogenous and exogenous factors in the management of ethnic relations in Serbia. Starting with the endogenous factors, since 2000, the engagement of Vojvodinian Hungarian parties (VMSZ) has been centring on a preference to the politics of consensus over the politics of confrontation. Capitalizing on the state of fragmentation in Serbian politics since the fall of Slobodan Milošević and prior to the consolidation of SNS, VMSZ had been participating in a series of government coalitions with larger Serbian parties on the republican level and at the provincial government of Vojvodina. Since 2000, this pattern of engagement has facilitated VMSZ to promote their standpoints and demands on minority rights from within the halls of power. At the same time, although this document still maintains a great symbolic value, VMSZ appears to place a secondary importance to the tripartite concept of ethno-territorial autonomy as the fundamental premise for anchoring the party's policymaking. ${ }^{10}$

The consolidation of SNS as the dominant actor in Serbian politics did not affect the management of ethnic relations. The political programme of SNS subscribes to safeguarding the collective rights and freedoms of ethnic minorities as these are stipulated in the state legislation (education, political representation, public use of minority languages, and crossborder links to the kin states) (SNS, 2011, pp. 44-45). More importantly, following the results of the 2016 elections for the Vojvodinian assembly, VMSZ has been steadily cooperating with the provincial SNS committee over a broad range of policy areas. ${ }^{11}$ Empirical research demonstrates that SNS and Aleksandar Vučić have been keen on a tactical and 
situationally adaptive pattern of policymaking with the objective to maintain a favourable balance vis-à-vis a wide range of interest groups (Petsinis, 2017; Vuksanović, 2018).

At the same time, the role of Hungary as the external homeland for Serbia's ethnic Hungarians has been readjusted. On numerous occasions, the question of minority rights for ethnic Hungarians fomented tensions between Budapest and neighbouring governments (e.g. Hungary's objections during Romania's EU accession process and its opposition to the Slovak Language Law of 2009). Although the situation of the ethnic kin in the 'near abroad' still forms a priority of Hungarian foreign policy, the EU's apprehension over the state of democratic freedoms in Hungary, as well as Viktor Orbán's principled opposition to certain EU guidelines (e.g. the refugee quotas arrangement), have largely shifted the lens of the Hungarian government's grievances from the neighbouring states towards Brussels. Politically active individuals among Vojvodina's Hungarian community have also hinted at the inter-personal modus vivendi between President Vučić and PM Orbán. They underline that VMSZ leader István Pásztor functioned as the key mediator between the two statesmen. ${ }^{12}$

Moreover, the endeavour by the nationalist and irredentist party of Jobbik to expand its bases of support among Vojvodina's Hungarians has not been fruitful (Pogonyi, 2017, pp. 104-105) and was met by strident opposition from VMSZ. In January 2014, István Pásztor warned Jobbik, on the occasion of the party's attempt to inaugurate its representation office in Subotica, that 'we do not need anyone, not a single one, who comes from Hungary to ignite fire with their irresponsible behaviour, and then go home', and added that 'Vojvodina's Hungarians have never been and will never become protagonists in either Serbian or Hungarian nationalism'. ${ }^{13}$

By contrast, Russia's role, as the external homeland for Latvia's ethnic Russians, has constantly been confrontational. As early as 2000, the Kremlin responded to Latvia's perceived nationalizing project by dubbing the country a 'frontrunner in the discrimination of the Russian-speaking population', whereas, in 2003, Dmitry Rogozin went as far as to prescribe economic sanctions and contend that 'Nazis have come to power in Latvia' (Van Elsuwege, 2004, pp. 1 and 28). Furthermore, between 2003 and 2004, Russia tried to indirectly complicate Latvia's accession process to the EU by bringing up the question of minority rights in Latvia at the sessions of the COE and the OSCE (Muižnieks, 2006b, pp. 124-125). Most recently, Russia has been accused of trying to jeopardize societal security in Latvia via means of information warfare, disinformation campaigns in the social media and even the sponsorship of separatism in the southeast region of Latgale (Berzina, 2016, pp. 7-20; Ozolina, 2016). ${ }^{14}$

One might argue that Russia's much greater geopolitical weight and confrontational tones have not engendered positive developments for the collective status of ethnic Russians in Latvia but, instead, they seem to backfire. By contrast to the Serbian case, this aggregate of endogenous and exogenous catalysts has resulted in maintaining the convergence between ethnopolitics and geopolitics intact. Following a long string of debates between 1998 and 2004, the '60-40' principle was agreed upon and specified that public secondary schools were to deliver at least $60 \%$ of the instruction in Latvian and the remaining $40 \%$ in a minority language of choice (mainly Russian) (Nakai, 2014, pp. 69-70; Zepa et al., 2006, p. 27).

Nevertheless, to the eyes of most political parties at the Latvian parliament (Saeima) and other stakeholders, any attempts at further concessions in the area of minority rights might bring about societal polarization and pave the path to concessions in the field of inter-state 
relations with Russia (Cianetti, 2014, pp. 101-102). The language referendum of 2012 was an initiative that polarized the society and highlighted the cleavages over the ethnic democracy model and its implementation (Hanovs, 2016; Ijabs, 2016, pp. 10-12). ${ }^{15}$ Consequently, Latvian remains the only official language in the public administration even in Latgale and other parts of the country with a compact Russian-speaking population.

\section{The Role of the EU as a Fourth Actor: Enabling versus Disabling Circumstances}

In Serbia, the clearer demarcation of geopolitics from ethnopolitics drastically facilitated the engagement of the EU and its soft power as a fourth actor. In a series of bilateral negotiations with Serbian government representatives, the European Commission reiterated to their interlocutors that the rearrangement of the legal framework on minority rights not only would conform to the accession requirements of the Copenhagen Criteria, but it would also contribute towards the resolution of any outstanding issues with neighbouring states (e.g. Hungary and Croatia) (Anastasakis, 2008). ${ }^{16}$

The provisions of the Law on the Rights and Freedoms of National Minorities (2002) and the other legal documents on minority rights are fully consistent with the guidelines of the Framework Convention for the Protection of National Minorities (FCNM, 1994) in regards to the prohibition of discrimination (Articles 4.1, 5.2, and 6.2 of the FCNM), the public use of minority languages (Article 11.1-2), the operation of media in minority languages (Article 9.3), the provision of education for ethnic minorities at all levels (Articles 12.1$2,13.1$, and 14.2), and the authorization of minorities to maintain links to legal subjects based in their kin states (Article 17.1). ${ }^{17}$ On the regional level of Vojvodina, the statute on provincial autonomy (2014) effectively recycles and combines selected elements of the Communist era legislation with the European standards on minority rights. ${ }^{18}$

During Latvia's accession stage, the EU and its soft power engagement played a decisive part towards the relaxation of the strict version of the ethnic democracy model and the more effective inclusion of the ethnic Russian minority (Schutze, 2018, pp. 260-274). This was particularly the case with the allowance for the children of non-citizens born after independence to obtain citizenship by registration and through the abolition of the language requirement for deputy candidates (Cianetti, 2014, pp. 97-98; European Commission, 2002, pp. 20, 25, 27, 30-31, 33, 135, and 141; Van Elsuwege, 2004, pp. 9-10 and 51). Nevertheless, the persistence of the convergence between ethnopolitics and geopolitics operated as a 'glass ceiling' that froze more drastic developments during the post-accession period.

Russia's emergence as a contender to the EU and NATO from the East additionally prompted a string of Latvian governments to place a greater stress on regional security rather than on the domestic management of ethnopolitics (Schutze, 2018, pp. 134-164). Therefore, lesser attention was paid to the liberalization of minority policies whereas a greater emphasis was laid on perfecting the other aspects of democratization (consolidation of the democratic institutions and the rule of law, media freedom, and privatization of the economy). Consequently, in contrast to Serbia, the persistent convergence between geopolitics and ethnopolitics in Latvia limited the opportunity structure towards the liberalization of the legal framework on minority rights and/or the substantial revision of the ethnic democracy model.

The attention paid towards establishing Latvian as the official language in order to, allegedly, boost integration (e.g. the Latvia National Action Plan, 2004-2006) was often interpreted by interest groups among the ethnic Russian community as an attempt to disguise assimilation into integration (Van Elsuwege, 2004, pp. 12-16; Zepa et al., 2006, p. 23). 
Furthermore, throughout 2017 and 2018, ethnic Russian interest groups regarded the proposals for Latvia's educational reform as a subtle endeavour to 'engulf' Russian-language schooling institutions. ${ }^{19}$

\section{Geopolitics, Ethnopolitics, and the EU in Serbia and Latvia: The Party Politics Dimension}

\section{The Outlooks of the Contenders}

The 1990s were marked by the solid convergence between ethnopolitics and geopolitics in Serbia. This convergence was reflected on the 'anti-imperialist' critique of Euro-Atlantic institutions which was propagated by the ruling Socialist Party of Serbia/SPS. ${ }^{20}$ Within the frame of this hegemonic narrative, Serbia and the Federal Republic of Yugoslavia not only were under threat from the geopolitical machinations of the EU and NATO, they were equally imperilled from the destabilizing initiatives of 'fifth-column' political organizations in the interior. In regards to ethnic relations, SPS and its party branches issued statements such as, 'the Socialists will fight against all these local forces that aim to fragment or separate Vojvodina from Serbia, namely the League of Vojvodina's Social Democrats, the Democratic Community of Vojvodina's Hungarians and the Democratic Union of Vojvodina's Croats'. ${ }^{21}$ Under the leadership of Vojislav Šešelj, the, radical right-wing Serbian Radical Party/SRS adopted this convergence between geopolitics and ethnopolitics and concretized it even further (Bakić, 2009, pp. 194-203).

In its present party manifesto, SRS makes no explicit references to the EU but clarifies that the party prioritizes the formation of political and military alliances with: ' $\ldots$ those states that have understanding for Serbia's national interests ... those states that expressed solidarity (to Serbia) during its toughest moments in history' (SRS, 2009, p. 28, 30). SRS judges that: '... Serbia has no reason to become member of international alliances that favour the interests of certain groups of states at the expense of others' (ibid., p. 29; Bakić, 2009, p. 199). In all of this, the party no longer attempts to draw any links between its opposition to EU institutions and the management of ethnic relations within Serbia. In a separate section, SRS holds that 'throughout the past 50 years, the rights of the national majority had been violated, whereas the members of the national minorities had been privileged' (SRS, 2009, p. 28).

The reformation and decision of the erstwhile centre-right, Democratic Party of Serbia/ DSS, to form a coalition with the more nationalistic Dveri ('Gates') in 2014 concretized this party's shift further to the right. Departing from their accusations of the EU over the alleged disregard of Serbia's national interests in Kosovo, DSS/Dveri gradually expanded its Eurosceptic platform to the economy. The party does not object to the maintenance of bilateral cooperation with EU member states (e.g. Germany, Italy, and Austria) but rejects Serbia's accession process to the EU and favours the establishment of closer connections to Russia and the BRICS (Stojić, 2017, pp. 247-250). As it is the case with the 'new' SRS, DSS/ Dveri does not draw any links between its Euroscepticism and minority issues. Instead, both SRS and DSS/Dveri have switched their focus towards the migration crisis and object to the accommodation of war refugees from the Middle East in Serbia. ${ }^{22}$ Nevertheless, neither of these two parties possesses considerable electoral weight. ${ }^{23}$

By contrast to Serbia, as early as the restoration of independence, the desire for a 'return to Europe' via joining the EU emerged as an imperative in Latvia (Austers, 2016, pp. 87- 
88; Austers \& Ņikišins, 2017). During the 1990s, the (radical right-wing) political party of TB/LNNK ('For Fatherland and Freedom') opted for the renationalization of the state, objected to the relaxation of the legal criteria for the naturalization of the 'Soviet era colonists', and even proposed their 'conditional repatriation' to Russia (Björkman-Bennich \& Johansson, 2012, pp. 8-9).

The pressures from the High Commissioner on National Minorities (OSCE) for the revision of the Law on the State Language (1998-1999) were interpreted by TN/LNNK as an affront and a sign of negligence, as well as external interference, to Latvia's domestic affairs (ibid., p. 8; Jubulis, 2001, pp. 128-129; Kelley, 2004, pp. 83-84). Nevertheless, even though insisting on the maintenance of the convergence between geopolitics and ethnopolitics, the party did not harden its outlook on the EU accession process. Instead, since that early stage, TB/LNNK concentrated its efforts towards the renegotiation of specific aspects of the EU's conditionality which, according to the party, clashed with Latvia's national interest and state sovereignty. ${ }^{24}$

\section{The View from within the Halls of Power}

SNS subscribes to Serbia's EU accession process as a trajectory which is expected to enhance the country's democratic institutions, accelerate economic growth, and modernize the state's infrastructure (SNS, 2011, p. 40). In all of this, the ruling party opts for military neutrality and envisages Serbia's global role as 'a bridge between East and West' that should be open to cooperation with global actors as diverse as the US, China, Japan, and Russia (ibid., p. 41). In specific regards to the bilateral relations with Russia, the party manifesto underlines the necessity to promote the Orthodox and Slavic cultural bonds between the two nations (ibid.). As the former party chairman and Serbian President Tomislav Nikolic stated on a series of occasions, 'Serbia wants to join the EU because it is an organized family of nations ... but, at the same time, we have a close historical and religious connection to the Russian Federation'. ${ }^{25}$

At a first glance, one might argue that SNS inherited selected aspects from the programme of the 'old' SRS on Serbia's global neutrality and modified them along the lines of conditional endorsement to the EU accession process. One might even draw some, however non-linear and tentative, correlations to the legacies of Yugoslavia's participation in the non-aligned movement. In all of this, though, one should not underestimate the importance of pragmatic and timely considerations. In addition to the promotion of political and economic stability, the SNS-led government further legitimizes the accession process to the EU through reference to the existence of a vibrant Serb diaspora in Central and North-Western Europe as well as to the export-import ratio between EU and Serbia (Đukić, 2015, p. 35). ${ }^{26}$

At the same time, though, Russia is Serbia's staunchest ally at the UN Security Council in regard to the question of Kosovo. Since 2008, the Serbian government has established a steady cooperation with Gazprom (Subotić, 2011, p. 322), and Russia remains a key partner in energy cooperation. Moreover, the ongoing impact of the economic and migration crises throughout the EU functions, if only subtly, as an additional incentive for Serbian policymakers to prolong Serbia's geopolitical oscillation between East and West (Vuksanović, 2018). Serbian policymakers tend to reflect upon the Croatian precedent and the widespread belief that Croatia did not reap all the economic benefits that it anticipated from EU membership (Samardzija, 2016, pp. 131-132, 134). As an aggregate of all 
abovementioned catalysts, Serbian government officials tend to occasionally criticize the EU over its alleged bias vis-à-vis the collective status of ethnic Serbs in Kosovo (or, secondarily, the relations between Serbia and Republika Srpska) (Pavlović, 2015). This criticism is frequently coupled with statements of gratitude to Russia as Serbia's most powerful patron regarding Kosovo. ${ }^{27}$

In greater detail, President Vučić has reiterated, in a series of interviews to Russian media outlets, that 'I feel very comfortable about Vladimir Putin's words of further support for Serbia's territorial integrity which is not only an issue of Serbia, it has become an issue for many sovereign states'. ${ }^{28}$ At the same time, the Serbian President has been issuing charges of 'double standards' and/or 'hypocrisy' against powerful EU member states along the lines that: 'How can Serbia open a Pandora's Box? Who opened this Pandora's Box in 2008 having accepted, acknowledged, and recognized the unilaterally proclaimed independence of Kosovo? They were doing so, not us! 29

Meanwhile, the relaxation of the intersection between ethnopolitics and geopolitics has dissociated the criticism of the EU over geopolitics from the question of ethnic relations within Serbia. For a start, the recognition of Kosovo's independence by powerful global actors (e.g. the US in 2008) and the consolidation of its governing institutions resulted in the transformation of the Kosovo question from one that once pertained to the sphere of domestic ethnopolitics into one that currently pertains to the sphere of foreign policy and regional geopolitics.

Moreover, the readjustment of Hungarian foreign policy, the normalization of relations with Croatia, and the continuous participation of VMSZ in the established governing structures hint at the absence of a security threat emanating from any of the minorities in Vojvodina. Politically active individuals within the ethnic Hungarian minority may even juxtapose VMSZ's consensus approach to the, allegedly, more confrontational attitudes espoused by the political representatives of other minority groups (e.g. the Bosnjaks of Sandžak). ${ }^{30}$ Under these circumstances, SNS regards the existence of ethnic minorities as a 'strength and wealth of Serbia' and judges that 'the violation of the constitutional and legal arrangements on the individual and collective rights of ethnic minorities represents a direct threat to the Serbian national interest' (SNS, 2011, p. 43).

In Latvia, the fusion between TB/LNNK and the 'All for Latvia!' party into the National Alliance/NA in 2011 represents a milestone in the history of the country's populist and radical right (Auers \& Kasekamp, 2015, p. 141). Taking advantage of the cordon sanitaire around Harmony, NA had been accepted as a legitimate partner in two coalition governments (2011 and 2014). The party leadership clarifies that 'NA primarily views Latvia's membership of the EU as a geopolitical and security related issue ... we do not subscribe to Mr Juncker's concept of Euro-federalism because it is seriously flawed'. ${ }^{31}$ Moreover, NA remains adamant in its position that the convergence between geopolitics and ethnopolitics must remain intact, especially considering that the 'Kremlin's weaponization of the "Russian world" concept is visible in Latvia ... the contemporary "Russian World" concept is reminiscent of the Völksdeutsche concept in the days of Nazi Germany'. ${ }^{32}$

Since 2015, the EU refugee quotas arrangement has emerged as an additional point of contention between NA and the Commission. The party underlines the pre-emptive character of its engagement against the admission of Muslim refugees in Latvia and, in Raivis Zeltits' words, 'If you look at the UK or France, ghettoization, crime, and the spread of Islamic fundamentalism constitute an explosive blend. Latvia is and will remain safe if it manages to escape the migration waves'. ${ }^{33}$ In light of the geopolitical confrontation with 
Russia and the migration crisis, the party leadership tends to place a lower importance on domestic ethnopolitics, yet hints that 'we are afraid that our Western partners often cannot relate to our trauma inherited from the Soviet era and our concerns over Latvia's security and state sovereignty (e.g. their relentless pressures over the naturalization of stateless persons)' 34

Overall, one might argue that NA has been promoting a pattern of policymaking within which geopolitics, ethnopolitics, and 'new' identity politics (namely, anti-immigration) intercede with each other. By contrast to the consolidation of occasionally critical outlooks on the EU from within the governing structures in Serbia, NA's 'right-wing entryism' to the halls of power has not prompted a more 'Eurosceptic' turn in Latvia's foreign policy (Auers \& Kasekamp, 2015, pp. 151-152). Instead, the party has been mostly successful in promoting its policies on demographic issues (ibid., pp. 142-143) and spearheading its proposals for Latvia's educational reform from within the government structures.

\section{Realities on the Ground}

Moving to the grass-roots dimension, public surveys, conducted between 2001 and 2002, detected very positive inclinations vis-à-vis the prospects of Serbia joining the EU as well as an apprehension towards 'the West' and the firm rejection of NATO (Lazar \& Marinković, 2001; NNS, 2001; Puzigaca \& Molnar, 2001, p. 19). These ambivalent observations can be comprehended, on the one hand, on the basis of the desire to end the country's prolonged isolation and, on the other hand, as the result of the NATO bombing and the Western policies towards Serbia during the 1990s. The favourable disposition in regard to the EU accession process persisted until the early 2010s (Kancelarija za Evropske Integracije, 2010, p. 3; Marković-Tomić, 2016). Nevertheless, since 2014, there has been observed a steady decline in the favourable attitudes towards the EU accession process and the pro-EU percentages in the public surveys have been fluctuating between $55 \%$ and $45 \%$ of the samples polled (CESID, 2016, pp. 24-25; Kancelarija za Evropske Integracije, 2014, p. 4).

The reluctant or negative attitudes vis-à-vis the EU seem to correlate with the Serbian government's oscillation between East and West in that they revolve around perceived controversies with the EU policies on Kosovo and other regional geopolitics and fears that the EU membership may not contribute a lot to the improvement of Serbia's economic situation (Ministarstvo za Evropske Integracije, 2017, p. 6; 2018, p. 6 and 25). To these should be added the long-term impact of 'conditionality fatigue' (Ministarstvo za Evropske Integracije, 2017, p. 9). ${ }^{35}$ Meanwhile, there is no apparent linkage between unfavourable attitudes towards the EU and the management of ethnic relations within Serbia whereas the state of multi-ethnic cohabitation between the Serbian majority and ethnic Hungarians, as well as Croats, in Vojvodina remains positive (CESID, 2016, p. 35). ${ }^{36}$

By contrast to the sequence between pronounced Europhilia and more apprehensive modes in Serbia, Latvian public attitudes vis-à-vis the EU can be summarized as 'lukewarm'. In October 2003, a total of 67\% approved Latvia's accession process to the EU in the nationwide referendum (i.e. a lower percentage in comparison to Lithuania's $89.9 \%$ or Slovakia's 92.5\%) (Austers, 2016, p. 90). Furthermore, in contrast with the uniform desire to end the country's isolation in Serbia, positive outlooks on the EU membership appear to have been subject to different expectations among Latvians and ethnic Russians. In the former case, the geopolitical argument and the necessity to enhance Latvia's leverage vis-à-vis Russia had been of crucial significance (ibid., p. 102). ${ }^{37}$ In 
the latter case, membership of the EU was viewed by interest groups within the ethnic Russian community as a trajectory that would help improve the situation of minority rights (ibid., p. 92). ${ }^{38}$

The results of the latest Eurobarometer and other surveys hint at the prolongation of these lukewarm outlooks with $49 \%$ of the respondents 'trusting' the EU and $35 \%$ opting not to (Austers, 2016, p. 91; Eurobarometer, 2018, p. 2; SKDS, 2016). ${ }^{39}$ In regards to the Latvian respondents, their lukewarm and/or apprehensive attitudes vis-à-vis the EU seem to correlate with the positions of NA along the lines of insecurities over the EU's capacity to enhance Latvia's geopolitical weight in relation to Russia (especially following the repercussions of the Ukrainian crisis since 2014) (Berzina, 2016, p. 19) and suspicions that the EU may 'use' Latvia as a destination for the en masse relocation of migrants from the Middle East and North Africa (Austers, 2016, p. 95; Eurobarometer, 2018, p. 2; Murašovs, Ruža, Raščevskis, \& Dombrovskis, 2016, p. 62). ${ }^{40}$ In all of this, there is no apparent linkage between Eurosceptic attitudes among the Latvian majority and opposition to minority rights. Furthermore, there is no evidence that the controversy over the educational reform has additionally worsened the outlooks of ethnic Russians on the EU. Especially following the outcome of the latest economic recession (2009-2011), it is economic Euroscepticism which acquires a firmer foothold in society (Austers, 2014, pp. 9-37; 2016, pp. 96-101).

\section{Conclusions}

Latvia and Serbia are two states situated along the northeast and the southeast fringes of the EU periphery. Although the former is a full-fledged member state of the EU since 2004 and the latter remains stranded along the path of a complicated accession process, the management of ethnic relations has been interceded, to varying degrees, with geopolitical concerns in both countries, and this provides a crucial common denominator. This comparative study hints that as the bond between geopolitics and ethnopolitics grows more powerful, liberalization of minority policies within a given state becomes less feasible.

In Serbia, systemic transformation triggered the demarcation of the intersection between domestic ethnopolitics and regional geopolitics. This combined with the endorsement of consensus politics by the largest minority party (VMSZ) and the impact of exogenous factors, the most important of which being the change of course in Hungary's neighbourhood policy. Within a longer trajectory, the aggregate of these developments facilitated EU's external engagement as a fourth actor. By contrast, in Latvia, the convergence between geopolitics and ethnopolitics remains intact, and therefore the opportunity structure towards further liberalising the legal framework on minority rights has been more restricted in comparison to Serbia. In all of this, one should not overlook Russia's emergence as a contender to the EU and NATO from the East. This development further prompted a string of Latvian governments to place a greater stress on regional security rather than on the domestic management of ethnopolitics.

This comparative study also demonstrates that the intersection between geopolitics and ethnopolitics should not be perceived as 'fixed', but it can be subject to fluctuations and readjustments. This means that, under certain circumstances, the centrality of domestic ethnopolitics can weaken. The discussion of Serbia demonstrates that the readjustment of the intersection between ethnopolitics and geopolitics shifted the lens of the country's main political actors primarily towards geopolitics. Meanwhile, the discussion of Latvia demonstrates that new variables can enter the fore (i.e. the 'new' anti-immigration identity politics, 


\section{V. Petsinis}

compounded by economic anxieties) and temporarily challenge the primacy of regional geopolitics and domestic ethnopolitics.

This comparative study aims at enhancing the cross-regional exchange of knowledge between the Western Balkans and the Baltic States. Such cross-regional comparisons are necessary in order to set in context how the interaction between endogenous and exogenous actors can impact the engagement(s) by the EU in the field of minority rights, to varying degrees and within different contexts.

\section{Funding}

This work was supported by H2020 Marie Skłodowska-Curie Actions [grant number 749400].

\section{Notes}

1. http://ec.europa.eu/enlargement/enlargement_process/accession_process/criteria/index_en.htm (accessed on 14 November 2018).

2. The bulk of this piece was completed before the formation of the new government after the Latvian parliamentary elections of October 2018.

3. This piece casts its focus on: (a) Serbia's most ethnically diverse region, the autonomous province of Vojvodina (Table 1); (b) the largest and politically organized minority group, the ethnic Hungarians (251\%, $136 \%$ or $13 \%$ of Vojvodina's population in 2011).

4. I refer to 'ethnic Russians' on the basis that Russia is the state that functions as the external homeland of Latvia's Russophones. 542,469 ethnic Russians are estimated to reside in Latvia (July 2018 figure).

5. SNS garnered $48.25 \%$ of the vote in the parliamentary elections of 2016 and Aleksandar Vučic $55.06 \%$ of the vote in the presidential elections of 2017.

6. United Nations Security Council, Resolution 1244 (including annexes 1 and 2), Adopted by the Security Council at its 4011th meeting on June 10th, 1999, Distr. GENERAL, S/RES/1244 (1999).

7. https://news.err.ee/635146/latvia-s-saskana-party-ditches-agreement-with-putin-s-united-russia (accessed on 15 October 2018).

8. Harmony secured $19.80 \%$ of the vote and emerged as the strongest party in the October 2018 elections. This had also been the case in the 2011 and the 2014 elections, where it garnered $28.36 \%$ and $23 \%$ of the vote respectively.

9. Throughout the period between 1995 and 2018, 145,941 persons (including 14,533 underage children) were granted the citizenship of Latvia. For these figures, see: http://www.pmlp.gov.lv/en/assets/ documents/naturalizija33/Naturaliz\%C4\%81cija\%20_j\%C5\%ABlijs2018/Stat01_2018_angl.pdf (accessed on 10 November 2018). Nevertheless, 237,719 Russian-speakers remained stateless by July 2017. For this figure, see: http://www.pmlp.gov.lv/lv/assets/documents/Iedzivotaju\%20re\%C4\% A3istrs/010717/ISVP_Latvija_pec_VPD.pdf (accessed on 11 October 2018).

10. VMSZ's concept of tripartite autonomy comprises the areas of personal autonomy, territorial autonomy, and local self-administration. On this issue, see: VMSZ, Proposal for an agreement on the self-organization of Hungarians in Vojvodina (The concept of the Alliance of Hungarians in Vojvodina), Novi Sad, January 18th, 1996.

11. The party chairman, István Pásztor, currently serves as president at the executive council of the provincial assembly.

12. Interviews with: VMSZ MP at the Serbian parliament (30 November 2018, Belgrade); Vice secretary on national minorities at the autonomous assembly of Vojvodina (29 November 2018, Novi Sad).

13. For this statement, see: http://www.vesti-online.com/Vesti/Srbija/377296/Pastor-Jobiku-Ne-vrsljaj-poVojvodini (accessed on 20 November 2018). Interview with Vice secretary on national minorities at the autonomous assembly of Vojvodina (29 November 2018).

14. Interviews with two research experts in information warfare at the National Defence Academy of Latvia, (7 July 2017).

15. The result of the referendum was decisively against the motion to recognize Russian as the second state language $(74.08 \%)$ but reflected upon the ethno-cultural divisions within the society and hinted that the ethnic Russian population did not subscribe to the recognition of Latvian as the sole state language. 
16. Article 6 of the statute on the autonomy of Vojvodina restored the collective status of the ethnic Croat minority in regard to the areas of education and public information in the Croat language. On this issue, see: 'Statut autonomne pokrajine Vojvodine' in Službeni list AP Vojvodine, br. 20/2014.

17. The Serbian law on the use of minority languages is also consistent with Articles 8.1 (education), 9.1 (judicial authorities), 10.1-2 (public administration), 11.1 (media) and 14 of the European charter for regional or minority languages, (COE, 1995).

18. Two noteworthy examples are the statute's authorization for: (a) the election of the national minorities' councils at the provincial assembly; (b) the national minorities to cooperate with legal subjects based in their kin states as well as the ban on ethnic discrimination and the propagation of ethnic hatred. Similar provisions were in force as part of the Vojvodinian Constitution (1974) (Articles 4 and 194) and its complementary legislation.

19. Interviews with: two ethnic Russian journalists and political activists, (7 July 2017, Riga); two Professors in Latvian party politics at Latvia University, (28 July 2017, Riga); a National Alliance representative at the Latvian Saeima and the European parliament, (13 October 2017, Riga); https://eng.lsm.lv/article/ society/education/legality-of-latvias-education-reform-to-be-considered-by-constitutional-court.a277041/ (accessed on 10 October 2018).

20. Interviews with sociologist at the Faculty of Philosophy, University of Novi Sad (26 November 2018); advisor at the NDNV-Novi Sad, media NGO (1 December 2018).

21. Declaration of the 3rd congress of the Vojvodinian SPS committee (issued in January 1996) in Socijalistička Partija Srbije- Pokrajinski Odbor SPSa u Vojvodini, 'Vojvodina 2000. Korak u novi vek- izveštaj', Novi Sad 1996, p. 2.

22. On these issues, see: http://www.dss.rs/dss-protiv-trajnog-naseljavanja-migranata-u-pancevo/; http:// www.rts.rs/page/stories/sr/story/2660/izbori-2017/2679047/seselj-ogradom-ili-minskim-poljem-smanjitipriliv-migranata.html (accessed on 12 October 2018).

23. SRS garnered $8.10 \%$ and DSS/Dveri $5.04 \%$ of the vote in the parliamentary elections of April 2016.

24. This party had been in almost every government coalition since 1995: first as TB and LNNK separately, then also after their merge into TB/LNNK.

25. https://www.aljazeera.com/programmes/talktojazeera/2016/11/tomislav-nikolic-serbia-won-align-eastwest-161124105054362.html (accessed on 19 November 2018).

26. Economic transactions with EU member states amounted to $63.07 \%$ of the total external trade between 2017 and 2018. On this issue, see: http://www.stat.gov.rs/en-us/vesti/20180928-spoljnotrgovinskarobna-razmena-avgust-2018/?s=1701 (accessed on 19 November 2018). Meanwhile, Serbia's fragmented exports to Russia cannot counterbalance its imports from that country.

27. Interviews with former Serbian Minister of National Defence (20 November 2018, Belgrade); advisor at the NDNV-Novi Sad, media-NGO (1 December 2018).

28. https://www.rt.com/shows/sophieco/440384-vucic-kosovo-serbia-tensions/ (accessed on 12 October 2018).

29. Ibid.

30. Interview with a VMSZ MP at the Serbian parliament, (30 November 2018).

31. Interview with the Secretary general of the Latvian National Alliance, (13 October 2017, Riga).

32. Interview with a National Alliance representative at the Latvian Saeima and the European parliament, (13 October 2017, Riga).

33. Interview with the Secretary general of the Latvian National Alliance, (13 October 2017, Riga).

34. Interview with a National Alliance representative at the Latvian Saeima and the European parliament, (13 October 2017, Riga).

35. Interviews with senior researcher at Friedrich Ebert Stiftung-Serbia, (30 November 2018, Belgrade) and a team of researchers at the Novi Sad School of Journalism (28 November 2018).

36. One more opinion poll, conducted by the Institute for European Affairs-Belgrade (21-24 March 2018), found out that the majority of the respondents regarded Hungary as one of Serbia's friendliest neighbours. On this issue, see: http://iea.rs/2018/05/10/rezultati-istrazivanja-javnog-mnjenja-o-evropskoj-uniji/ (accessed on 13 November 2018).

37. On the comparable trends in Estonia during the same period, see: Aalto (2003, p. 26).

38. This wave of Europhilia declined as result of the widespread conviction, among the ethnic Russian community, that the EU's soft power was not enough. On this issue, see: Cianetti and Nakai (2017, p. 276); Interviews with one affiliate of the Harmony's youth organization (27 July 2017, Riga) and with two ethnic Russian journalists and political activists (7 July 2017, Riga). 


\section{V. Petsinis}

39. In Latgale, the polarization seems more evident with $54 \%$ of the polled sample (2015-2016) declaring their belonging to Europe and a percentage of 40.08 denying it (Berzina, 2016, p. 26; FACTUM, 2015). Moreover, $43.01 \%$ among the ethnic Russian respondents reiterated their identification with Europe and an additional $84.03 \%$ with Latvia (Berzina, 2016, p. 27).

40. Interview with the administrator of a local NGO (23 October 2017, Daugavpils).

\section{References}

Aalto, P. (2003). Constructing post-Soviet geopolitics in Estonia. London: Routledge.

Agarin, T. (2016). Extending the concept of ethnocracy: Exploring the debate in the Baltic context. Cosmopolitan Civil Societies, 1-19. doi:10.5130/ccs.v8i3.5144

Anastasakis, O. (2008). The EU's political conditionality in the Western Balkans: Towards a more pragmatic approach. Southeast European and Black Sea Studies, 8(4), 365-377.

Arpasy, I. (1996). The Hungarians in Vojvodina: Political condition of a minority in a nationalizing state (MA Dissertation). Budapest: Central European University Press.

Auers, D., \& Kasekamp, A. (2015). The impact of radical right parties in the Baltic States. In M. Minkenberg (Ed.), Transforming the transformation. The East European radical right in the political process (pp. 137-153). London \& New York: Routledge.

Austers, A. (2014). Latvia's controversial "success story”. In K. Bukovskis (Ed.), The politics of economic sustainability: Baltic and Visegrad responses to the European economic crisis (pp. 1-24). Riga: LIIA.

Austers, A. (2016). The case of Latvia: Popular Euroscepticism in impasse. In K. Bukovskis (Ed.), Euroscepticism in small EU member-states (pp. 85-107). Riga: LIIA.

Austers, A., \& Ņikišins, J. (2017). The sociology of Euroscepticism in the Baltic States. In A. Austers \& K. Bukovskis (Eds.), Euroscepticism in the Baltic States: Uncovering issues, people and stereotypes (pp. 149-207). Riga: LIIA.

Bakić, J. (2009). Extreme-right ideology, practice and supporters: Case study of the Serbian radical party. Journal of Contemporary European Studies, 17(2), 193-207.

Berzina, I. (2016). The possibility of societal destabilization in Latvia: Potential national security threats. Riga: National Defence Academy of Latvia.

Björkman-Bennich, L., \& Johansson, K. M. (2012). Explaining moderation in nationalism: Divergent trajectories of national conservative parties in Estonia and Latvia. Comparative European Politics, (online version). doi:10.1057/cep. 2011.28

Brubaker, R. (1995). National minorities, nationalizing states and external homelands in the new Europe. Daedalus, 124(2), 107-132.

Bruszt, L., \& Stark, D. (2003). Who counts? Supranational norms and societal needs. East European Politics and Societies and Cultures, 17(1), 74-82.

Budryte, D. (2005). Taming nationalism? Political community building in the post-Soviet Baltic States. Aldershot: Ashgate.

Bustikova, L. (2015). The democratization of hostility: Minorities and radical right actors after the fall of communism. In M. Minkenberg (Ed.), Transforming the transformation (pp. 58-79). New York: Routledge.

Bustikova, L. (2018). The radical right in Eastern Europe. In J. Rydgren (Ed.), The Oxford handbook of the radical right (pp. 1-22). Oxford: Oxford University Press.

Centre for Free Elections and Democracy (CESID). (2016). Javno mnenje Srbije: politička i društvena situacija u Srbiji. Belgrade: Author.

Cianetti, L. (2014). Granting local voting rights to non-citizens in Estonia and Latvia: The conundrum of minority representation in two divided democracies. Journal on Ethnopolitics and Minority Issues in Europe, 13(1), 86-112.

Cianetti, L., \& Nakai, R. (2017). Critical trust in European institutions: The case of the Russian-speaking minorities in Estonia and Latvia. Problems of Post-Communism, 64(5), 276-290.

Council of Europe. (1995, February 1). Framework convention for the protection of national minorities. European Treaty Series No. 157, Strasbourg.

Craiutu, A. (1995). A dilemma of dual identity: The democratic alliance of Hungarians in Romania. East European Constitutional Review, 4(2), 43-49.

Đukić, S. (2015). Serbia's relations with Russia: An overview of the post-Yugoslav (post-Soviet) era. In Challenges of Serbia's foreign policy (collection of papers) (pp. 31-36). Belgrade: Friedrich Ebert Stiftung.

Eurobarometer. (2018). Standard Eurobarometer 89 (Latvia, Spring 2018). 
European Commission. (2002). Regular report on Latvia's progress towards accession, (SEC 2002, 1405). FACTUM. (2015). Survey for the needs of the NADL's research on 'current security problems in Latvia'.

Hanovs, D. (2016). Can postcolonial theory explain Latvian politics of integration? Reflections on contemporary Latvia as a postcolonial society. Journal of Baltic Studies, 47(1), 133-153.

Haughton, T. (2007). When does the EU make a difference? Conditionality and the accession process in Central and Eastern Europe. Political Studies Review, 5, 233-246.

Ijabs, I. (2016). After the referendum: Militant democracy and nation-building in Latvia. East European Politics and Societies, 30(2), 288-314.

Ikstens, J. (2013). Latvia. In J.-M. De Waele, F. Escalona, \& M. Vieira (Eds.), The Palgrave handbook of social democracy in the European Union (pp. 470-487). Basingstoke: Palgrave-Macmillan (Kindle edition).

Jubulis, M. (2001). Nationalism and democratic transition: The politics of citizenship and language in post-Soviet Latvia. Lanham: University Press of America.

Kancelarija za Evropske Integracije. (2010). Evropska orijentacija građana Srbije: trendovi (decembar 2010). Belgrade: Government of the Republic of Serbia.

Kancelarija za Evropske Integracije. (2014). Evropska orijentacija građana Srbije: trendovi (jun 2014). Belgrade: Government of the Republic of Serbia.

Kelley, J. (2004). Ethnic politics in Europe: The power of norms and incentives. 2004. Princeton, NJ: Princeton University Press.

Korhecz, T. (1998). The rights of national minorities in Vojvodina: Legal norms and practice (unpublished work). Novi Sad, 1-23.

Lazar, Z., \& Marinković, D. (2001). Regional identity: Vojvodina's urban public research survey. Open University Subotica. Essays on Regionalization. Subotica: Agency for Local Democracy.

Marković-Tomić, M. (2016). Mediji i teme u vezi sa Evropskom integracijom Srbije u periodu 2002-2016. Belgrade: Government of the Republic of Serbia.

Melenshevich, A. (2007). Party systems in post-Soviet countries: A comparative study of political institutionalization in the Baltic States, Russia, and Ukraine. Basingstoke: Palgrave Macmillan.

Ministarstvo za Evropske Integracije. (2017). Evropska orijentacija građana Srbije: trendovi (decembar 2017). Belgrade: Government of the Republic of Serbia.

Ministarstvo za Evropske Integracije. (2018). Evropska orijentacija građana Srbije: trendovi (jul 2018). Belgrade: Government of the Republic of Serbia.

Minkenberg, M. (Ed.). (2017). Transforming the transformation? The East European radical right in the political process. London \& New York: Routledge.

Mole, R. (2012). The Baltic states from the Soviet Union to the European Union: Identity, discourse and power in the post-communist transition of Estonia, Latvia and Lithuania. London: Routledge.

Muižnieks, N. (2006a). Government policy and the Russian minority. In N. Muižnieks (Ed.), Latvian-Russian relations: Domestic and international dimensions (pp. 11-21). Riga: Latvia University.

Muižnieks, N. (2006b). Russian foreign policy towards "compatriots" in Latvia. In N. Muižnieks (Ed.), LatvianRussian relations: Domestic and international dimensions (pp. 119-130). Riga: Latvia University.

Murašovs, V., Ruža, A., Raščevskis, V., \& Dombrovskis, V. (2016). Expecting refugees in Latvia: Negative stereotyping. Economics and Business, 29(1), 56-64.

Nakai, R. (2014). The influence of party competition on minority politics: The cases of Latvia and Estonia. Journal on Ethnopolitics and Minority Issues in Europe, 13(1), 57-85.

Noutcheva, G. (2007). Fake, partial and imposed compliance: The limits of the EU's normative power in the Western Balkans. CEPS Working Documents No. 274.

Ozolina, Z. (2016). Social security: Conceptual framework. In Z. Ozolina (Ed.), Social security: Inclusion-exclusion dilemma. A portrait of the Russian-speaking community in Latvia (pp. 13-28). Riga: Zinatne.

Pavlović, S. (2015, March 30). Serbia's choice: EU membership or eastern promises? Open Democracy. Retrieved from https://www.opendemocracy.net/can-europe-make-it/srdja-pavlovic/serbia\%E2\%80\%99s-choice-eumembership-or-eastern-promises

Petsinis, V. (2016). Ethnic relations, the EU, and geopolitical implications: The cases of Estonia and Croatia. Ethnopolitics, 15(2), 230-244.

Petsinis, V. (2017, May 28). Enter Serbia’s ‘Orbán’? Aleksandar Vučić and his catch-all politics. Open Democracy. Retrieved from https://www.opendemocracy.net/author/vassilis-petsinis

Pettai, V. (2006). Explaining ethnic politics in the Baltic States: Reviewing the triadic nexus model. Journal of Baltic Studies, 37(1), 124-136. 


\section{V. Petsinis}

Pogonyi, S. (2017). Extra-territorial ethnic politics, discourses and identities in Hungary. London: PalgraveMacmillan.

Puzigaca, M., \& Molnar, A. (2001). Istraživanje javnog mnenja: autonomija Vojvodine. Novi Sad: SCAN.

Pytlas, B. (2015). The populist radical right in Central and Eastern Europe: Ideology, impact, and electoral performance. London \& New York: Routledge.

Saarts, T. (2011). Comparative party system analysis in Central and Eastern Europe: The case of the Baltic States. Studies of Transition States and Societies, 3(3), 83-104.

Salonari, V. (2007). Regulation of ethnic relations in post-Soviet countries: The cases of Latvia and Moldova compared. Treatises and Documents, 52, Ljubljana.

Samardzija, V. (2016). How Eurosceptic is Croatia? In K. Bukovskis (Ed.), Euroscepticism in small EU memberstates (pp. 124-143). Riga: LIIA.

Samardžić, M. (1998). Položaj manjina u Vojvodini. Belgrade: Centar za Antiratnu Akciju.

Schutze, J. L. (2018). Strategic frames: Europe, Russia, and minority inclusion in Estonia and Latvia. Pittsburgh: University of Pittsburgh Press.

SKDS. (2016). Survey for the needs of the NADL's research on 'current security problems in Latvia'. Riga: Marketing and Public Opinion Research Centre (SKDS).

Smith, D. (2002). Framing the national question in Central and Eastern Europe: A quadratic nexus? Global Review of Ethnopolitics, 2(1), 3-16.

Smith, D. (2003). Minority rights, multiculturalism, and EU-enlargement: The case of Estonia. Journal on Ethnopolitics and Minority Issues in Europe, 1, 1-39.

Smooha, S. (2001, October 13). The model of ethnic democracy. ECMI Working Papers, Flensburg: ECMI Press.

Serbian Progressive Party (SNS). (2011). Bela knjiga programom do promena. Belgrade: Author.

Serbian Radical Party (SRS). (2009). Program Srpske Radikalne Stranke. Belgrade: Author.

Stojić, M. (2017). Party-responses to the EU in the Western Balkans: Transformation, opposition or defiance? London: Palgrave-Macmillan.

Subotić, J. (2011). Europe is a state of mind: Identity and Europeanization in the Balkans. International Studies Quarterly, 55, 309-330.

Tarrow, S. (2010). The strategy of paired comparison: Toward a theory of practice. Comparative Political Studies, $43,230-259$.

The Novi Sad School of Journalism (NNS). (2001). Nacionalistička vrednosna orijentacija kao faktor otpora prema autonomiji Vojvodine. Novi Sad: Author.

Van Elsuwege, P. (2004). Russian-speaking minorities in Estonia and Latvia: Problems of integration at the threshold of the European Union. Flensburg: ECMI Press.

Vasilijević, S. 2002. The legal aspects of the protection of minorities in the process of stabilization and association. In K. Ott (Ed.), Croatian accession to the EU: Institutional challenges (Vol. 2, pp. 249-272), Zagreb: Institute of Public Finance.

Vuksanović, V. (2018, July 26). Serbs are not little Russians. The American Interest. Retrieved from https://www. the-american-interest.com

Zepa, B., et al. (2006). The aspect of culture in the social inclusion of ethnic minorities: Latvia. Flensburg: ECMI Press. 